\title{
The Prisoner, the Lover, and the Poet: The Devonshire Manuscript and Early Tudor Carcerality
}

\author{
MOLLY MURRAY \\ Columbia University
}

Les nombreux bouleversements de la culture politique des Tudors durant les années 1530 ont transformé les pratiques d'emprisonnement en Angleterre. Le développement rapide des lois sur la trahison par Henri VIII, joint à son désir de censurer et de contrôler son élite politique par des condamnations de nullité de droits civils (act of attainder), a envoyé un grand nombre de membres de la noblesse - hommes et femmes - dans les prisons de l'État anglais. Cet article se penche sur les cas de deux prisonniers nobles, Sir Thomas Howard et Lady Margaret Douglas, qui ont été incarcérés à la tour de Londres suite à leur mariage secret en 1536 et considéré comme politiquement indésirable. Pendant leur captivité, Thomas et Margaret ont composé et échangé plusieurs poèmes lyriques, maintenant conservés dans le manuscrit nommé le Devonshire Manuscript (British Library Additional Manuscript 17492). On montre dans cet article que, dans leur présentation matérielle, ces poèmes offrent un témoignage concret de la remarquable vie sociale présente dans la prison Tudor, et dans laquelle des hommes et des femmes interagissaient verbalement autant que par écrit. Le contenu de ces poèmes, ainsi que leur style, nous transmettent l'expression de leur amour, mais aussi des commentaires tranchants sur les pratiques carcérales innovantes d'Henri VIII.

$\mathrm{O}$ $\mathrm{n}$ the second day of May, 1536, Sir William Kingston, lieutenant of the Tower of London, took custody of Anne Boleyn, condemned to death by her husband on charges of adultery and treason. In a letter written the next day to Secretary Thomas Cromwell, Kingston reported the following exchange with his prisoner: "She said unto me, 'Mr. Kingston, shall I go into a dungeon?' I said 'No, Madam. You shall go into the lodging you lay in at your coronation" - - in other words, into the same royal apartments in the Tower that had been renovated, at great expense, only a few years earlier. "It is too good for 
me', she said," perhaps appreciating the irony of this repurposing. ${ }^{1}$ Kingston's correspondence suggests that Anne faced her reversal of fortune with a general black humour; when told of the French headsman to be brought in especially for the occasion, for instance, "she said, 'I heard say the executor was very gud, and I have a lytel neck', and put her hand abowt it, lawynge [laughing] hartely."2 Two of Anne's other reported comments, however, bear more serious consideration. First, "she sayd, Mr. [Kingston, shall I die with] owt justes [justice]? And I sayd, the porest sugett [subject] the Ky[ng] hath, hath justes. And there with she lawed [laughed]," perhaps at the idea of Henrician clemency. ${ }^{3}$ Then, she turned her attention to the comfort of the men imprisoned as her co-conspirators: her brother George, her musician Mark Smeaton, and the courtiers William Brereton, Richard Page, Henry Norris, Francis Weston, and Thomas Wyatt. She "asked my wyf [wife] whether heny [any] body maks thayr bed... [and $\mathrm{m}$ ]y wyf ansured and sayd nay, I warant you, then she say[d the] y myght make balettes well now." ${ }^{4}$ What begins as a straightforward question about prison housekeeping becomes a play on the near-homophones "pallet" (bed) and "balette" (song or poem). ${ }^{5}$ While Anne might be implying that the prisoners would make good subjects for popular ballads, the main force of her comment seems to be the juxtaposition of two kinds of "making": the elegant poetic inventions of courtiers like Rochford and Wyatt, and the bleak survival strategies of the prisoner.

This article will consider several "balettes" made in the Tower in the year after Anne's execution: a sequence of poems composed by Lady Margaret Douglas and Sir Thomas Howard, two members of the nobility imprisoned by Henry following their illicit courtship and marriage. Critics have taken occasional note of the manuscript miscellany that preserves these poems, now known as the Devonshire Manuscript, as an example of the poetic practices of the early Tudor nobility. ${ }^{6}$ In focusing on this particular sequence within the Devonshire, however, I will argue that the manuscript reflects not just the gendered politics of the Henrician court, but also, more particularly, the gendered politics of the Henrician prison. ${ }^{7}$ The poems composed and exchanged by Margaret and Thomas materially attest to the literary culture of the Tower of London and its lack of strict separation between men and women, courtiers and prisoners. They also constitute the couple's pointed response to their imprisonment at the King's pleasure, in both theme and form. As even the most cursory reading will attest, the lyric poetry of the early Tudor 
period resonates with metaphors of "bondage," "enthrallment," "durance," and "service" in descriptions of love - even the King himself would write lines like "Alac! Alac! What shall I do? / For care is cast in to my heart, / And true love locked thereto." The Devonshire Manuscript shows Thomas and Margaret redirecting these all too familiar tropes and figures to describe - and implicitly to critique - the particular Tudor penal innovations under which a lover might become, in fact, a captive. In their redeployment of literary convention, the love poems of Thomas and Margaret mark the charged intersection of power, gender, and imprisonment that characterized the later years of Henry's rule.

\section{Attainted love and the Henrician prison}

Henry VIII's increasingly autocratic and centralized style of politics has received ample historiographical attention. ${ }^{9}$ Less often noted is that this consolidation of royal power transformed the English prison, especially the Tower of London, into a dark analogue of the court itself: a place where authority could be displayed and privileges gained or lost, an antechamber where noble subjects waited upon the monarch's favour and feared his wrath. This newly carceral mode of Henrician "justes" appears most strikingly in Henry's politically pivotal imprisonments of noble women on the grounds of erotic imprudence. In the cases of his queens Anne Boleyn and Catherine Howard, Henry's charge of adultery was also, ipso facto, a charge of treason, and punishable by death. By placing Anne in the same Tower chamber on the eves of her coronation and execution, however, Henry made a further point coldly and elegantly clear: that the highest political elevation and the lowest disgrace rested equally and entirely within his royal will. In a letter allegedly written to Henry from the Tower in 1536, Anne describes her "agony and vexation" at her vertiginous fall, helplessly noting that "your Graces displeasure, and my imprisonment, are things so strange to me, as what to write, or what to excuse, I am altogether ignorant."10 Anne's professed ignorance of her offence may have been exaggerated, but her description of imprisonment as something "strange," lacking any explanation beyond the king's "displeasure" and thus admitting no possible "excuse," indicates the political climate in the mid-1530s - a time when, in the words of Sir Anthony Waite, "it is amongst the people rumoured that one should be com- 
mitted unto the Tower because he hath said that this month shall be rainy and full of water; the next month, death; and the third month, wars."

Such fears were not entirely unfounded; the King's new domestic arrangements and ecclesiastical policies were accompanied by a rapid and radical expansion of the English laws of treason. Historically, treason had been defined chiefly as an act or credible threat of physical violence against the crown. Under Henry and his ministers, this was broadened after 1534 to include any acts of speech and writing that challenged the new Acts of Succession or Supremacy. The newly-redefined category of "misprision of treason," in turn, made knowledge of such intended treason itself treasonable, further enabling Henry to punish his political enemies. ${ }^{12}$ Starting in the late 1530s, in other words, English men and women could be found guilty of treason on more grounds than ever before. Moreover, and still more disturbingly, Henry also increasingly employed an entirely extra-legal means of punishment, the parliamentary attainder, to censure and control his courtly elite. The attainder, or legislated declaration of guilt, had long been available to English kings as a supplement to law, used particularly to seize the lands of convicted traitors who had eluded the reach of punishment either by dying or fleeing the country. ${ }^{13}$ Henry VII had used the attainder to convict those who posed a particular and pressing danger to his realm, but only very occasionally; his son seems to have used similar restraint from his accession in 1509 to $1533 .{ }^{14}$ Starting with his break from Catherine of Aragon, however, Henry would rediscover the attainder as an efficient means of confining and condemning his enemies without cumbersome and time-consuming judicial proceedings. ${ }^{15}$ With the administrative assistance of Cromwell, Henry used the attainder with unprecedented frequency throughout the 1530s and 1540s, summarily convicting men and women whose transgressions had yet to be classified as treason, or perhaps would never qualify as such under English law. Some of these imprisonments would end in execution, while others would end in release; K.J. Kesselring has perceptively described Henry's wielding of power through the pardon, an action that demonstrated his power to mete out life as well as death. ${ }^{16}$ Imprisoned victims of the attainder thus found themselves in a particularly bewildering predicament, "guilty" of high crimes only retroactively or temporarily defined as such, with no certain punishment mandated in law, and always admitting the tantalizing possibility that the king might demonstrate his mercy as capriciously as his wrath. The prison, in other words, served as the physical index of a new political contingency. 
The King's first high-profile use of the parliamentary attainder against his nobility came shortly after the execution of Anne Boleyn, and further demonstrated the increasingly volatile intersection of gender and politics in the English court of the 1530s. In the words of the Tudor herald Charles Wriothesley,

The Lord Thomas Haward, yongest brother to the Duke of Norfolke, was sent to the Tower of London for making a privie contracte of matrimonie bewteen the Ladie Margarett Duglas and him... and the said Lord Thomas was atteynted by the hoole Perliament for the said contracte, as shall appeare by an act of Perliament made for the same; and also the Ladie Margarett Duglas was comitted after to the Tower of London, also for the same. ${ }^{17}$

The lady in question, Margaret Douglas, had been at court since the age of sixteen and, as the daughter of Henry's sister and the Scottish Earl of Angus, held a significant place in the Tudor succession. Margaret became still more important to the Tudor line after Anne's execution, when both Princesses Mary and Elizabeth had been declared illegitimate, and when Henry had yet to produce a male heir with his new queen, Jane Seymour. At precisely this moment, the King discovered that his niece had secretly contracted a marriage with Sir Thomas Howard: the scion of a dangerously ambitious political dynasty, as well as a relative of the late, disgraced Queen Anne. ${ }^{18}$ This "privie contracte of matrimonie," however undesirable it may have been to the King, had nonetheless not violated any existing English law. Henry accordingly turned to the parliamentary attainder as a means of convicting the pair. The act passed for the purpose, 29 Henry VIII c. 24, declared the marriage a threat to "the hole peace unyte rest and quyetnes of this realme and of the subjects of the same." It alleged that Thomas "craftely and trayterously hath imagyned and compassed, that in case our seid Sovereign Lord shuld die wythout heyres of his bodye" he might himself pretend to the throne as the husband of the King's niece. Such marital ambition, the Act declared, constituted high treason; to safeguard against similar mesalliances in future, the Act concluded by classifying as equally treasonable any marriage to a female member of the royal family, or any "attempt or defyle or deflower any of them not being maried... without the speciall license assent consent and aggrement... of the Kyngz Highnes in wrytyng." Margaret, for her 
part, was attainted of misprision of treason for her role in the marriage, and both she and her husband were sent to prison without trial. ${ }^{19}$

Such harsh treatment of Thomas and Margaret struck many as hypocritical on Henry's part, particularly after his scandalous divorce of his first wife and recent imprisonment and execution of his second; Imperial Ambassador Eustace Chapuys, for example, sarcastically noted that Margaret "deserved pardon [for her illicit marriage], seeing the number of domestic examples [of erotic misconduct] she has seen and sees daily." ${ }^{20}$ Margaret was, eventually, pardoned and released - but only after she had sufficiently abased herself before the King's authority and abjured her ill-advised match. In an undated letter to Cromwell, Margaret thanks Cromwell for "gyv[ing] me knowleg wherin y might hawe hes graceys desplesuer again," and asserts that "y wyll never do that thyng wyllyngly that shuld offend hes grace." In case the message of abjection wasn't clear enough, she urges Cromwell "not to thynk that eny ffancy doth remayn in me touchyng [Sir Thomas], but that all my study and car ys now to plese the kyngs grace." The terms that Margaret uses, reminiscent of Anne's, indicate the highly tenuous status of a prisoner who has caused the King's "desplesuer" not by "wyllyngly" violating any existing legal statute, but — in this case - through what she herself describes (and implicitly excuses) as merely an ill-advised "ffancy... touchyng" the wrong man. "My lord," she continues, "as for resort y promes you y hawe non except yt be gentylwemen that comes to se me, nor never had sens y cam hether for yf eny resort of men had com yt shold nother becum me... to have kept them company beyng a mayd as y am." ${ }^{21}$ This promise to "plese" the King and forswear her husband eventually earned Margaret's release - though not before Thomas died of an ague in the Tower in November 1537.

Margaret's letter to Cromwell expresses the existential confusion likely felt by the object of an act of attainder, forced to appeal to the King's "pleasure" rather than the law of the land. At the same time, her reference to potential callers at her place of confinement also gestures toward another significant consequence of Henry's penal innovations: the creation of a noble "company" or community that blurred any hard and fast lines between the courtly and the carceral. Indeed, the King's increasingly capacious definition and harsh prosecution of treason had, by the 1530 s, dramatically altered the population of state prisons. The majority of inmates in the pre-Tudor Tower of London had been high-ranking prisoners of war, both foreign and domestic: Frenchmen, 
Scots, Welsh, and English noblemen who had fought or conspired with rebel factions or rival claimants to the throne. ${ }^{22}$ In the first decades of Tudor monarchy, this trend continued. In September 1513, for example, Queen Catherine wrote to Cardinal Wolsey about procuring servants for the captured Duc de Longueville, a French nobleman taken at the Battle of Spurs; several days later, we find a bill for masonry on the doors and windows "where the Frenchman should be kept in ward within this the King's Tower of London."23 Longueville exemplified an earlier kind of high-ranking military prisoner, held captive in relative comfort, and ransomed according to longstanding conventions of chivalry and international law. Starting in the 1530s, however, the Tower began to hold a wider array of English courtiers whose crimes consisted not in explicit or violent rebellion against the King, but rather in contradicting the royal will in religious and domestic matters. The more noble of these prisoners lived in lavish conditions: a record of expenses for the Earl of Surrey's prison lodgings in the Tower notes "six peces of hangynges of tapestry worke," "one fether bed" and assorted bedding, and several pieces of "the Kinges Majesties plate which the sayd Erle hadd in his chamber," including gilt flagons and basins. ${ }^{24}$ Surrounded by such royal appurtenances, Surrey — like Anne Boleyn, awaiting death in her coronation chamber - would have been materially reminded of the Tower's paradoxical status as both a state prison and a royal palace. Other noble captives were permitted the "resort" of courtly friends and associates in their cells; social gatherings such as that between the imprisoned Margaret Douglas and her "gentylwemen" would further underscore the proximity and intersection of courtly and carceral life.

Within this evolving, permeable prison culture, the place of women might be described as especially and consequentially liminal. As James Daybell and others have shown, Tudor women frequently acted as advocates for imprisoned male relatives or other associates. ${ }^{25}$ In a letter written from prison to Lady Honor Lisle in 1535/36, for instance, one Thomas Hall begs for her "pity and compassion on me, that through your gracious procurement to my lord I may be delivered hereout of prison. ${ }^{26}$ Hall presumes that Lady Lisle, as a prominent member of a powerful political family, would be ideally positioned to intercede on a prisoner's behalf. Hall's mention of "my wife which is the bearer unto your ladyship of this letter," moreover, reveals another aspect of female carcerality in the period: free women physically moving in and out of the prison, facilitating correspondence between prisoners and the outside world. Occasionally, wives 
would even be permitted to cohabitate with their imprisoned husbands, and these women would be permitted to leave periodically to conduct family business. The few female prisoners of whom we have some record did not seem to be granted the same privilege of marital cohabitation - perhaps because their husbands were presumed to share culpability for their crimes, and were accordingly imprisoned elsewhere. But, like their male counterparts, imprisoned noblewomen were not always kept in solitude; many received visitors, particularly female visitors - and, as we will see, these visitors could be the agents of literary collaboration, as well as emotional solace, political alliance, or legal advocacy.

\section{"Gentyll letters" and the social textuality of the Tudor prison}

At first glance, the quarto volume known as the Devonshire Manuscript seems a straightforward illustration of the literary culture of the early Tudor court. The poems composed and compiled by its various owners and users exemplify the vernacular verse forms gaining popularity among the English elite in the earlyto mid-sixteenth century: from native ballads and Chaucerian borrowings to newly fashionable strambotti, frottole, canzoni, and fourteen-line Petrarchan sonnets. ${ }^{27}$ The hands that fill most of its pages have been attributed to members of the Henrician nobility, including three high-ranking court ladies: Mary (Howard) Fitzroy, sister to the Earl of Surrey and wife of Henry's illegitimate son; Mary Shelton, Anne Boleyn's cousin; and, above all, Margaret Douglas — whose hand appears more frequently than any other throughout the volume. ${ }^{28}$ Editors have long valued the Devonshire as a key manuscript source for lyrics by Thomas Wyatt and the Earl of Surrey, both connected to the compilers by blood or marriage; more recently, scholars have used the Devonshire to argue for the importance of women in the creation and transmission of courtly literature. So, for Jonathan Goldberg, the inscriptions of Shelton, Fitzroy, and Douglas destabilize the idea of single (male) authorship in the period, while for Paul Remley, Shelton's choice of poems to inscribe indicates a "dissentient response to some of the incivilities of the Henrician court." ${ }^{29}$

Poems 7-14 of the Devonshire (folios 26r-30r), however, invite us to think more specifically about the carceral world of early Tudor England, the intimate "company" kept by courtly men and women across prison walls, and the role of 
literature, specifically poetry, in negotiating these boundaries. This sequence of short poems has been attributed to Thomas Howard and Margaret Douglas by most scholars of the manuscript, as it presents a pair of speakers (identified in the text as "T.H." and "margrt.") who lament the "great paynes" and "untollerabul sorrowes" caused by their recent separation and confinement in "prison stronge." In addition to their complaints, the speakers of these poems also allude to an ongoing correspondence that has bolstered their mutual constancy. In one poem, for example, "T.H." bids his lady farewell, "Trustyng that shortely I shall here / From yow the stay off all my lyfe / Whose helth alone ys all my chere." Later, he refers to her "gentyll letters," to which, he promises, "both I and my penn... wyll apply." Such written communication within the Tower would have been difficult, but by no means impossible. Sir Thomas More, one of the king's most high-profile prisoners of state, not only exchanged letters with family and friends outside the Tower, but also managed to communicate with his fellow prisoners of conscience within it. Under interrogation, More admitted to corresponding with his fellow Catholic Archbishop Fisher, explaining that "as they were both in one prison, and for one cause, he was glad to send to him, and hear from him again." ${ }^{30}$ The interrogation further revealed that this correspondence was maintained and concealed with the help of servants. Richard Wilson, one of Fisher's attendants, admitted that he had "conveyed about a dozen letters between More and Fisher, some being written with ink, and some with coal" (and often conveyed with some subterfuge; after admitting that "he took a pot of conserve from Fisher to Ant. Bonvise [Antonio Bonvisi]," Wilson quickly assured his questioners that "there were no letters in the pot"). ${ }^{31}$ The key figure in this system of exchange seems to have been George, a servant to the lieutenant of the Tower, whom Wilson "often suspected... of carrying letters between my lord and Mr. Moor."32 George also seems to have taken responsibility for destroying evidence of this correspondence; asked to produce some of the letters he received from Fisher, More replied that "he would have had George to keep them, and George always said there was no better keeper than the fire."33

A suggestive comment made by Margaret to Cromwell after Thomas's death hints that a similar scenario, involving complicit servants, might explain how such "gentyll letters" travelled between the two. Addressing Cromwell's concerns about the size of her retinue at Sion House, Margaret replies " $y$ hawe but ii mo then y had in the court wych in ded wer my lord thomas sarvands and the cause that $y$ tok them for was for the poverty that $y$ saw them in." 34 
Margaret, in other words, had given employment to her late husband's former servants after her own release from the Tower, a gesture that might suggest her gratitude as well as her charity. Perhaps these "sarvands" had been in Thomas's employ during his imprisonment, and helped carry their "gentyll letters" from one prison cell to another. Perhaps these loyal servants even committed their correspondence to the fire rather than leaving it to be discovered by enemies - which explains why none of it has survived. Or, perhaps these "gentyll letters" do survive after all, in the very lyrics preserved in the pages of the manuscript. Throughout the sequence, a number of internal echoes and allusions comprise a recognizable dialogue across poems. For instance, after several poems in which "T.H." proclaims his refusal to renounce his marriage, "For thretnyng nor for punysment" (9:16), a poem ascribed to "margrt" celebrates such displays of constancy by echoing their language:

Wyth thretnyng great he hath ben payd

Off payne and yke off punnysment,

Yet all fere asyde he hath layed:

To loue me best was hys yntent. (12: 9-13)

She declares her mirrored intent to "loue hym best" and, in an implicit rebuke to the attainder's depiction of Thomas as a pretender to royal power, asserts that

Yff I had more, more he should haue

And that I kno he knowys full well;

To loue him best vnto my graue

Off that he may both bye and sell. (12: 17-20)

Here, Margaret both reassures Thomas of her devotion and at the same time announces to any other readers that their marriage was consensual, and that Thomas deserves any material advantage he might have gained from it. In the next poem, “T.H." expresses his gratitude for such an expression of magnanimity:

[Such] faythfullnes ye dyd euer pretende

And gentylnes as now I see

Off me wych was yowr pore old frend, 
Yowr louying husband now to be;

Synce ye desende from your degre

Take ye thys vnto yowr part,

My faythful, true and louyng hart. (13:15-21)

In these lines, Thomas acknowledges his lady's acknowledged willingness to marry below her "degre," as expressed in the foregoing poem. Instances like this suggest that the sequence is, itself, a versified prison correspondence, one in which the two lovers refer and respond to their respective expressions of devotion, as well as their shared experiences of misfortune - and do so not only for each other, but for a wider courtly public.

The inclusion of these poems in the Devonshire volume thus offers material evidence not only of Thomas and Margaret's communication within the prison, but also of the cooperation and collaboration of courtiers outside its walls. The entries on these pages are all written in a single hand, which is not that of Margaret herself; Helen Baron, ascribing the hand to Thomas, hypothesizes that he had the book with him in the Tower before his death in 1537, and there inscribed the poems that he and Margaret had recently exchanged..$^{35}$ Paul Remley, ascribing the hand to Mary Shelton, suggests that she "facilitate[d] the secret correspondence" between Thomas and Margaret, then copied that correspondence into the book at a later date. ${ }^{36}$ Such a scenario does not seem unlikely; under interrogation, many members of their courtly circle confessed that they had assisted the couple's clandestine meetings before their marriage. Thomas Smyth, for example, while denying that he carried tokens between the two lovers, admits that "Margaret's women" had likely done so; "Being asked whether he had seen him (lord Thomas) resort unto her when my lady of Richmond was present; he says divers times, insomuch that he would watch till my lady Boleyn [likely Thomas Boleyn's wife] was gone, and then steal into her chamber. Examined whether he hath been there with him (lord Thomas); he answers, sundry times." ${ }^{37}$ Given the complicity among friends and relatives in the surreptitious progress of the affair at court, it seems entirely likely that Shelton, or one of her associates, would have helped Thomas and Margaret exchange verse letters in the Tower, and would moreover have ensured that these letters earned a permanent place in the volume that would preserve their shared literary efforts for posterity. 
A poem entered on a later page offers the further, still more tantalizing suggestion that Margaret may also have had the volume briefly in her possession while a prisoner either in the Tower or at Sion House. Poem 37, sixteen lines written in Margaret's hand, appears among several other poems attributed to Margaret's female friends as well as to Thomas Howard, indicating that the book circulated rapidly among them with each contributing a poem or two. ${ }^{38}$ In this particular sequence of poems, however, Margaret's single contribution is the only one not written in ink; it is, instead, inscribed with smudged pencil or charcoal, a medium often used by early Tudor prisoners. ${ }^{39}$ Its sorrowful female speaker, moreover, occupies precisely Margaret's own situation in 1536: she is "caught [kept] fro [her lover's] spech, hes syght and company," but defiantly insists that "in spyt of hes ffo [his foes]," she will "gyve loue and kep [her] ffantesy." The image of Margaret writing this poem in her cell, then handing the book over to Mary Shelton or another courtier with whom she "kept company" in the prison, can only be speculative. The writing medium may not hold any particular significance, and Margaret may have composed the poem either before or after her imprisonment. Yet, even without conclusive evidence that either Margaret or Thomas had the book itself in their possession in the Tower, the Devonshire still offers powerful proof that not just petitions, prayers, and letters, but also secular poems could and did circulate through the walls of the Tower. In this sense, the volume literally embodies the permeability of courtly and carceral culture, its pages physically linking the imprisoned lovers not only to each other, but also to their circle of friends and literary collaborators.

\section{Style, allusion, and the prison poet}

However sustaining these poems may have been for Thomas and Margaret, they have not been received particularly kindly by generations of critics. So, for example, H.A. Mason harrumphs that "these lovers, faced with such a serious menace, contrived to exchange the most banal and wishy-washy verses in Wyatt's emptiest style - such stuff in fact as, taken by itself, would lead us to talk of their love as a half-hearted game." ${ }^{40}$ Mason's comment, though pejorative, is nonetheless accurate in describing the relative lack of literary originality in the sequence. None of these seven poems develops a new verse form, and all of them draw heavily on Petrarchan commonplaces of love and longing found 
elsewhere in this volume and in other verse miscellanies of the period. It would be hard to deny, moreover, that a quatrain like

Who hath more cawse for to complayne

Or to lament hys sorow and payne

Then I whych louys and louyd agayne

Yet cannot optayne? (11:1-4)

lacks the subtlety and finesse of, say, Wyatt's "Blame not my lute," another poem preserved in the pages of the Devonshire. ${ }^{41}$ Yet the terms of Mason's dismissal imply that to be unoriginal is to be "banal," to employ familiar tropes and figures is to eschew sincerity, and that literary games cannot be meaningful. I want to suggest that what we might too quickly deride as "empty style" actually constitutes a deliberate and subtle response to the new style of Henrician imprisonment as I have described it. The effectiveness of these poems as comment and critique, in fact, derives precisely from their assertive unoriginality.

In the first place, by composing instances of fashionable secular verse, and by refusing to adopt the stance of the pious, suffering prisoner, Thomas and Margaret demonstrate their ongoing, vigorous participation in the cultural world beyond the prison. In this way, these poems reflect the particular realities of Henrician imprisonment far more precisely than do Thomas More's betterknown "Tower Works," composed after his refusal to accept Henry's break from Rome. In the De Tristitia, the Dialogue of Comfort, and his letters, prayers, and meditations, More represents his prison experience in terms of archetypal Christian sufferings, particularly those of the "imprisoned" Jesus of the Gospels and the speaker of Boethius's Consolation of Philosophy. God, More writes, has "made me content in my harte, to lese good, land, and lyfe too, rather than to swere against my conscience," and indeed the King "hath done me so great good by the spirituall profytt that I trust I take therby, that among all his great benefites heaped upon me so thicke, I reken upon my faith my prisonment euen the very chief." ${ }^{2}$ More insistently interprets his own specific "prisonment" in terms of God's general providence. Here and throughout his prison writings, More blurs the specifics of penology and personality, and puts in their place an abstracted portrait of imitatio Christi and contemptus mundi, expressing what Garry Haupt has called "his tenacious commitment to an objective, 
impersonal, universal order of Christendom" in which trial leads inexorably to transcendence..$^{43}$

Contrasting sharply with More's pious expressions of isolated suffering and heavenly reward, Thomas and Margaret's poetry uses the features of secular, vernacular lyric to reassert the importance of subjective, personal relationships on earth. These poems both bolster the bonds of "company" among their friends and relatives, and indict the particular penal innovations that have separated the lovers themselves. Margaret's seemingly bland praise of her "faythfullyst louer" in poem 12, for example, implies the continued integrity not only of her marriage but of the circle of readers to whom she speaks - underscoring her defiance, meanwhile, of those who would "let [hinder] me then off ryght... hym to retane" through actions like the attainder. Indeed, by invoking a knowing readership in this way, these poems enact the lovers' stated insistence on "retaning" their connections to the social world that the Henrician attainder has "hindered." Helen Baron has persuasively suggested that several other poems in the volume, written in a similar style, were likely composed by the pair during their courtship, well before arriving in the Tower. ${ }^{44}$ Tropes of love and service, longing and fidelity, mark the manuscript as a whole, and the contributions composed and compiled by other members of this circle outside the prison. By composing and exchanging poems in this same style from within their Tower lodgings, the lovers imaginatively repair the rupture figured by their imprisonment at the king's pleasure. For Thomas and Margaret, in other words, literary convention acts as a kind of talisman or go-between, carried by the prisoner across the carceral threshold, and functioning as a conceptual tie to the life from which he or she has been provisionally banished by royal decree. Stylistically and substantively, these poems demonstrate how early Tudor prison life might remain closely interwoven with the "free" world of the court.

But this sequence of poems also, and more crucially, refashions these familiar poetic conventions into a commentary on the poets' new and deeply unconventional circumstances. Discussing the love lyrics of the fifteenth-century English prisoner Charles d'Orléans, Joanna Summers and Anne Coldiron have each noted how Charles uses the figurative arsenal of amour courtois (longing lover, cruel mistress, etc.) to efface his particular plight as a prisoner of war. ${ }^{45}$ For Charles, the composition of love poetry is a means of imaginative escape from the carceral here-and-now. For Margaret and Thomas, by contrast, conventional literary formulae clearly indicate their specific predicament: placed in 
"prison stronge" by direct royal command, without basis - or remedy - in law. "Alas," begins one of Thomas's poems, "that men be so vngent / To order me so creuelly! / Off ryght they shold them self repent / Yff they regard there honesty" (10:1-4). The lover here describes his plight as the result not of his own trespass or his lady's withholding, but of the capricious "order" of hypocritical men, perhaps Tudor government functionaries, who are as "vngent" (ungentlemanly) as they are powerful. The poem's speaker invokes and refuses the solution offered to Thomas Howard by the king and his emissaries, rejecting the "doubyll tonge and flaterynge tayle" which would "allure" him to renounce his illicit marriage, and thus regain his freedom:

I thynke they wold that I shold swere

Your company for to forsake

But ons ther ys no worldly fere

Shal cawse me such an othe to make. (10:13-16)

In an eroticized version of political dissidence, “T.H." declares his unwillingness to take any "othe" against his conscience as a lover. Indeed, his avowed fidelity to his lady seems to grow in proportion to the pressure placed on him to renounce it. "Let them thynke and let them say," Thomas declares, "Toward yow alone I am full bent" (9:19-20). The defiant "let them say," meanwhile, reminds his reader that his and Margaret's imprisonments originated in words: convicted by the words of the attainder, betrayed by the words of some of their former associates, Thomas and Margaret suffered under orders, oaths, and rumours as well as bodily "paynes." In such a prison-house of language, the discourse of Petrarchan love is more than "empty style." Its storehouse of conventions, particularly the idea of erotic constancy withstanding political pressure and physical separation, provides the terms of resistance.

The most powerful poem in this vein is, in fact, the least "original" poem in the sequence. Here, "T.H." claims to offer a belated response to his lady's "gentyll letters," which he prefaces with a couplet of authorial recusatio: "And now my pen, alas, wyth wych I wryte, / Quaketh for drede off that I muste endyte" (14:1-2). These two lines, however seemingly heartfelt, are in fact not Thomas's own; they are lifted verbatim from William Thynne's 1532 edition of Chaucer's works, specifically the proem to Book 4 of Troilus and Criseyde, where the narrator enters his own poem to beg the reader's indulgence. After 
ventriloquizing Chaucer in this couplet, Thomas then assumes the voice of Chaucer's hero in the following four stanzas:

$\mathrm{O}$ very lord, $\mathrm{O}$ loue, $\mathrm{O}$ god, alas!

That knowest best myn hert and al my thowght,

What shall my sorowful lyfe donne in thys case

Iff I forgo that I so dere haue bought

Syns ye [ ] and me haue fully brought

Into your grace and both our hertes sealed,

Howe may ye suffer, alas, yt be repealed?

What maye doo I shal whyle I may dure

On lyve, in torment and in cruel payne,

Thys infortune, or thys dysaventure

Alone as I was borne I wyl complayne

Ne neuer wyl I sene yt shyne or rayne

But ende I wyl as Edyppe in derkenesse

My sorowful lyfe and so dy in dystresse.

$\mathrm{O}$ wery goste that errest to and fro

Why wyld thow not flye owt off the wofullest

Body, that euer myght on grounde go?

O soule, lurkyng in this woful nest

Flye forth my herte and yt breste

And folowe alwaye [ ] thy lady dere!

Thy ryght place ys nowe no lenger here.

O ye louers that hygh vpon the whele

Ben sette of fortune in good aventure,

God grawnte that ye fynden aye loue of stele

And longe may yowr lyfe in ioye endure;

But whan ye comen by my sepulture

Remembre that yowr felowe resteth there

For I louyd eke, thowgh I vnworthy were. (14:3-30) 
These lines are taken directly from Troilus's lament, uttered in desolation after his lady Criseyde has been handed over to the Greeks in exchange for the Trojan captive Antenor. ${ }^{46}$

H. A. Mason, we might imagine, would not have thought much of this "poem"; indeed, some critics who have written about the Devonshire Manuscript do not include it among the volume's original compositions at all. ${ }^{47}$ This Chaucerian appropriation, however, acts as a more extreme version of the same double deployment of literary convention - as a gesture of both cultural continuity and political critique - that I have been discussing as the larger imaginative strategy of this piece of prison writing. Considered purely thematically, Troilus's language allows Thomas to bewail the "dysaventure" that has left him equally "alone" and bereft of his lady - rehearsing and so inhabiting another literary lover's expression of sorrow and isolation. Considered as a cultural performance, however, Thomas's appropriation of Chaucer also implicitly challenges any too-easy association of imprisonment with solitude. Instead, and precisely by means of its reproduction, this lament of the solitary Chaucerian lover links the imprisoned pair of Henrician lovers to each other, to their lives before (and potentially after) incarceration, and to a wider community of readers and writers.

First, in material terms, Thomas most likely did not have this extended passage of Troilus and Criseyde committed to memory, and thus must have had a source text with him in prison, perhaps even Thynne's large printed folio. He may have brought this text with him upon his entry into the Tower, or he may have had temporary access to it during a visit from one of his friends or family. Either way, Thomas's lengthy Chaucerian quotation further demonstrates the traffic in texts, and the possibility of literary exchange, within and across the walls of the Henrician Tower. The allusion itself, meanwhile, conceptually and stylistically links these prison poems to a practice of medieval commonplacing that was widespread in early Tudor verse miscellanies. ${ }^{48}$ Other sections of the Devonshire Manuscript, sections that Baron ascribes to Thomas and dates from an earlier phase of the lovers' courtship, include extensive quotations from the Letter of Cupid, La Belle Dame sans Mercy, and the Remedy of Love, all pseudoChaucerian texts included in the Thynne volume. ${ }^{49}$ Read in light of these earlier transcriptions, Thomas's use of Troilus's language here is more than a borrowed lament: it is also another assertion of continuity and solidarity with cultural life beyond the prison. 
This is not the only way, however, that Thomas wears his Chaucer with a difference. In his particular choice of excerpt, he also fashions a complex and multi-layered commentary, not just on the situation of the lovelorn courtier but also on the situation of the Tudor political prisoner. In the first place, the passage in its original context alludes to a moment of Greco-Trojan realpolitik that would have obviously recalled Thomas's and Margaret's situation in 1536-37. This episode in Chaucer's poem begins in "time of trewe," when both sides of the war meet, "hir prisoners to chaungen, meste and leeste" (IV.59). The Greeks offer their prisoner Antenor in exchange for Criseyde, daughter of the Greek traitor Calchas, and the Trojans agree:

... delibered was by perlement,

For Antenor to yelden out Criseyde.

And it pronounced by the president,

Al-theigh that Ector 'nay' full ofte preyed;

And fynaly, what wight that it with-seyde,

It was for nought; it muste ben and sholde,

For substaunce of the perlement it wolde. (IV.211-31)

An expedient political decision, in other words, results in the summary removal of Criseyde, who will be henceforth held “among the Greekis stronge." Hector's objection, that such an exchange of a free woman has no precedent in law or custom ("we vsen here no wommen for to selle" [IV.182]), goes unheeded; the exigencies of politics (and, in the figure of Criseyde's traitorous father, of family) destroy the lovers' Trojan idyll. This part of Chaucer's plot bears particular relevance to the Howard-Douglas marriage and its consequences, and not just because, as Seth Lerer has argued, Margaret Douglas had, like Criseyde, "lived as the object of personal desire and political exchange" at court. ${ }^{50}$ More significantly and more specifically, what Troilus laments is an innovative, authoritative declaration by Parliament in the voice of its "president," one that results in the permanent physical separation of a "sealed" pair of lovers, and one against which there can be no further legal or procedural recourse ("it muste ben and sholde / For substaunce of the perlement it wolde"). For Thomas and Margaret, imprisoned by Henry's innovative, authoritative use of the parliamentary attainder, this vision of an erotic union thwarted by an act of unpredictable, irremediable political will would have been especially resonant. The transcription 
of Troilus's lament thus draws the reader's attention not to the general plight of separated lovers, but to the plight of two Tudor prisoners separated by a specific and nearly unprecedented kind of decree. Allusion, here, becomes critique; the familiar sorrows of fin'amor implicate, by contrast, the unfamiliar brutality of Henrician power.

In his appropriation of this section of the poem, moreover, Thomas also finds a way to represent the simultaneous harshness and indeterminacy of his and Margaret's imprisonment. Chaucer here describes the "dysaventure" of his titular lovers in ways that are immediately and relentlessly physicalized: Troilus lives "in torment and in cruel payne," proleptically imagining his body's enclosure in a "sepulture." The "here" in the passage quoted by Thomas is a place of claustrophobic constraint; in its only image of liberation, Troilus bids his soul "flye forth" from "this woful nest" to follow his lady. In Chaucer's original, these images of confinement reflect Troilus's voluntary retreat "into his chambre... faste allone" (IV.220). By rehearsing them in this very different context, Thomas offers, on one level, a straightforward allusion to his own confinement in the Tower. But he also alludes to the contingency of that same confinement by making a single change to the lines he chooses to transcribe - a change that manipulates the poem's physical appearance on the page. While implicitly placing himself in the speaking position of Chaucer's hero, Thomas leaves spaces in the middle of lines 5 and 20, where the lady's name should appear (i.e "syns ye [ ] and me haue fully brought / Into your grace and both our hertes sealed..."). With these omissions, Thomas at once invites his reader silently to replace Chaucer's "Criseyde" with the metrically comparable "Margaret," and avoids the charge of treasonable lèse-majesté should the book fall into the wrong hands. ${ }^{51}$ By leaving his lady's name unwritten, however, Thomas also subtly diagnoses a political moment at which anyone, no matter her status or rank, might find herself on the wrong side of the king, and on the inside of a cell. Thomas's poetic lacunae, in other words, stand for the very rooms of the Tower itself: indiscriminate spaces waiting - with implacable blankness - for their next unwitting inmates.

Through such subtle reinhabitings and reimaginings of convention, the Howard-Douglas sequence of poems in the Devonshire Manuscript exemplifies a kind of writing practice inspired and enabled by a new kind of prison practice. In their familiar Petrarchan commonplaces and Chaucerian borrowings, the love poems of Thomas Howard and Margaret Douglas represent, and 
implicitly respond to, a radical political imprisonment with little antecedent in custom and no basis in law. The redeployment of literary tradition in these poems neatly demonstrates, by implicit contrast, Henry's disregard for precedent in his treatment of their authors. Materially, moreover, the sequence attests to the relative permeability and sociability of the Henrician prison, showing how two inmates might communicate with each other and with a wider circle of friends and relatives through the walls of the "pryson stronge." In all these ways, these poems not only constitute a gesture of reciprocal consolation between two prisoners, but also speak trenchantly to the temporal and spatial paradoxes of Tudor imprisonment itself.

\section{Notes}

1. Letters and Papers, Foreign and Domestic, of the Reign of Henry VIII, ed. J.S. Brewer, J. Gairdner, and R.H. Brodie (22 volumes, London 1862-1932), Volume X, no. 793 (Kingston to Cromwell, 3 May 1536). Subsequent references will give $L P$ followed by volume and item number.

2. LP X.910 (Kingston to Cromwell, [19] May 1536).

3. LPX.793.

4. LPX.798.

5. In the early sixteenth century the word "balette" (spelled in a variety of ways) referred to any light verse, and not necessarily to the topical and often slanderous narrative poetry popular in the following century: cf. the usage cited in the Oxford English Dictionary: "1521 State Papers Henry VIII I. 10 Mr. Almoner, in hys sermone, broght in the balates off 'Passe tyme with goodde cumpanye,' and 'I love unlovydde"' (Oxford English Dictionary 3rd. ed., s.v. "Ballad," accessed 16 June 2012, http://www.oed.com/). By 1536, Wyatt was known as a writer of such "balettes," as was Anne's brother Rochford. See Kenneth Muir, ed., The Life and Letters of Sir Thomas Wyatt (Liverpool: Liverpool University Press, 1963), p. 9.

6. The manuscript was first noted by E. A. Bond, "Wyatt's Poems," Athenaeum (27 May 1871), pp. 654-55. Its social context was first considered by A. K. Foxwell, $A$ Study of Sir Thomas Wyatt's Poems (London: University of London Press, 1911), and elaborated by Raymond Southall in The Courtly Maker: An Essay on the Poetry of Wyatt and His Contemporaries (Oxford: Blackwell, 1964), pp.15-22, and by Richard Harrier, The Canon of Sir Thomas Wyatt's Poetry (Cambridge, MA: Harvard 
University Press, 1975), pp. 21-54. For more recent accounts of the Devonshire Manuscript at court, see Arthur F. Marotti, Manuscript, Print, and the Renaissance Lyric (Ithaca: Cornell University Press, 1995); Seth Lerer, Courtly Letters in the Age of Henry VIII (Cambridge: Cambridge University Press, 1997), pp. 125-26, 143-57; and the ongoing electronic Social Edition of the Devonshire Manuscript, produced under the editorial direction of Raymond G. Siemens: http://en.wikibooks.org/w/ index.php?title=The_Devonshire_Manuscript\&oldid=2342228.

7. See Bradley J. Irish, "Gender and Politics in the Henrician Court: The HowardDouglas Lyrics in the Devonshire Manuscript (BL Add 17492)," Renaissance Quarterly 64 (2011), pp. 79-114. Irish provides the fullest account to date of this section of the manuscript in its courtly as well as philological contexts.

8. See Peter C. Herman, ed., Reading Monarchs Writing (Tempe, AZ: Arizona Center for Medieval and Renaissance Studies, 2002), p. 220. See, however, the separate essay in the volume by Herman as well as Ray Siemens, "Henry VIII and the Poetry of Politics" (pp. 11-34), which discusses Henry's use of Petrarchan formulae (particularly the "bondage of love") to reassert his political power.

9. The classic account of these developments is G. R. Elton's The Tudor Revolution in Government: Administrative Changes in the Reign of Henry VIII (Cambridge: Cambridge University Press, 1953); Elton describes the enforcement of the Henrician reformation, in particular, in Policy and Police: The Enforcement of the Reformation in the Age of Thomas Cromwell (Cambridge: Cambridge University Press, 1972). For a survey of some of the major historiographical challenges to Elton's thesis, see D. Starkey and C. Coleman, eds., Revolution Reassessed: Revisions in the History of Tudor Government and Administration (Oxford: Clarendon Press, 1986), esp. pp. 53-54, 199-208.

10. Quoted in Lord Herbert of Cherbury, Life and Reign of King Henry the Eighth (1632), p. 446. Herbert notes that this letter "is said to be found among the papers of Cromwell," but no copy is extant.

11. Lisle Letters II.396, 27 May 1535.

12. 26 Hen VIII. c. 13. For an authoritative legal history of the subject see John G. Bellamy, The Tudor Law of Treason: An Introduction (London: Routledge, 1979). For a fascinating exploration of the literary effects of treasonable speech law, although at a slightly later historical moment, see Rebecca Lemon, Treason by Words: Literature, Law and Rebellion in Shakespeare's England (Ithaca: Cornell University Press, 2006); Susan Stewart offers a more suggestive theorization of the 
transgressive potential in the literary act itself in Crimes of Writing: Problems in the Containment of Representation (Oxford: Oxford University Press, 1991).

13. Bellamy, p. 11.

14. S. E. Lehmberg, "Parliamentary Attainder in the Reign of Henry VIII," Historical Journal 18 (1975), pp. 675-702, 677, 681; and Bellamy, p. 211. For Henry VII's earlier use of attainder, see J. R. Lander, "Attainder and Forfeiture, 1453-1509," Historical Journal 4 (1961), pp. 119-51.

15. William R. Stacy, "Richard Roose and the Use of Parliamentary Attainder in the Reign of Henry VIII," Historical Journal 29.1 (1986), pp. 1-15, 1.

16. K. J. Kesselring, Mercy and Authority in the Tudor State (Cambridge: Cambridge University Press, 2003).

17. Charles Wriothesley, A Chronicle of England during the Reigns of the Tudors, ed. W. D. Hamilton, 2 vols. (Camden Society, 1875), vol. 1, p. 54.

18. For further biographical details, see Irish, pp. 82-83. For a broader account of the Tudor dynasty's historically persistent Howard problem, see W. A. Sessions, Henry Howard the Poet Earl of Surrey: A Life (Oxford: Oxford University Press, 1999), pp. 19-139.

19. For a legal discussion of the case, see David M. Head, "Beyng Ledde and Seduced by the Devyll:' The Attainder of Lord Thomas Howard and the Tudor Law of Treason," Sixteenth Century Journal 13 (1982), pp. 3-16.

20. LP XI. no. 147 (Chapuys to Charles V, 23 July 1536).

21. BL Cotton MS Vespasian F.XII, fol. 241, Margaret Douglas to Thomas Cromwell [n.d.].

22. Record keeping in the medieval Tower was sporadic; for the best compilation of the extant evidence, see Brian Harrison, The Tower of London Prisoner Book (London: Trustees of the Royal Armouries, 2004). According to Harrison's lists, those who were not foreign prisoners of war were Jews or heretics, individuals who had physically attacked the king or his men, particularly violent felons, and prison officials who had failed to prevent an escape; cf. Jean Dunbabin, Captivity and Imprisonment in Medieval Europe, 1000-1300 (Basingstoke: Palgrave Macmillan, 2002), pp. 8-11. For the Tower's contrast with London's municipal and ecclesiastical prisons, see R. Pugh, Imprisonment in Medieval England (Cambridge: Cambridge University Press, 1968), pp. 103-57.

23. LP I.2226 and 2416.

24. TNA E/101/60/22, 38 Hen VIII, fol. 1. 
25. See James Daybell, “Scripting a Woman's Voice: Women's Epistolary Rhetoric in Sixteenth-Century Letters of Petition," Women's Writing 13.1 (March 2006), pp. 3-22, and the article by Alison Thorne in the same issue, "Women's Petitionary Letters and Seventeenth-Century Treason Trials," pp. 23-43.

26. Lisle Letters, III.598-99.

27. A thorough physical description of the manuscript is provided by Raymond Southall, "The Devonshire Manuscript Collection of Early Tudor Poetry, 1532-41," Review of English Studies, New Series XV.58 (1964), pp. 142-50; verse transcriptions can be found in Kenneth Muir, "Unpublished Poems in the Devonshire MS," Proc. of the Leeds Philos. and Lit. Soc. 6 no.1, pt. 4 (1947), pp. 253-82. Quotations from the manuscript will come from the transcriptions in Muir ("Unpublished Poems in the Devonshire MS") with emendations from my own transcriptions from the original manuscript when relevant.

28. See Paul G. Remley, "Mary Shelton and her Tudor Literary Milieu," in Peter C. Herman, ed., Rethinking the Henrician Era: Essays on Early Tudor Texts and Contexts (Urbana and Chicago: University of Illinois Press, 1994), pp. 40-77; Helen Baron, "Mary (Howard) Fitzroy's Hand in the Devonshire Manuscript," Review of English Studies, n.s. XLV.179 (1994), pp. 318-35; and Elizabeth Heale, "Women and the Courtly Love Lyric: The Devonshire MS (BL Additional 17492)," The Modern Language Review, 90.2 (1995), pp. 296-313.

29. Jonathan Goldberg, Desiring Women Writing: English Renaissance Examples (Stanford: Stanford University Press, 1997), pp. 144-63; Remley, p. 62.

30. LP VIII.867, no. 4.

31. LP VIII.856, nos. 33, 38.

32. LP VIII.856, no. 9 .

33. LP VIII.867, no. 3. The lieutenants' servants seem to have been notorious for helping prisoners to break rules; see Lisle Letters, II.150 for John Grenville's account of the aptly named "Bawde," a servant arrested in 1534 for helping a prisoner and his wife escape the Tower. Grenville laconically notes that “The King's Grace takes great displeasure with Mr. Lieutenant's negligence for suffering the keyes of the prison to be counterfeit" (For Bawde's confession see LP VII.418).

34. BL Cotton MS Vespasian F XIII, fol. 241.

35. Baron, p. 330.

36. Remley, p. 54. Remley notes that Mary Shelton's brother was employed in the Tower during this time.

37. LP XI.48. 
38. These poems appear on fols. 58-59 of the manuscript. Baron attributes them, respectively, to Margaret, Mary Shelton, Thomas Howard, and an unidentified hand (p. 331).

39. See, for instance, Thomas More's last letter to Margaret Roper from the Tower, which he describes as "written with a coal by your tender loving father."

40. H. A. Mason, Humanism and Poetry in the Early Tudor Period (London: Routledge, 1959), p. 167.

41. So Irish notes that the poems in this sequence often suffer by being "judged by the canonical standard of Wyatt's verse" (p. 91).

42. More, Correspondence, p. 531.

43. More, Collected Works, vol. 13, p. clxxx.

44. Baron, pp. 327-28; these poems are numbered 21-25 in Muir.

45. Joanna Summers argues that "there appears no link, direct or oblique, between Charles's political situation and his motivation for creating his English Book" of erotic lyrics, and that the text establishes an "ironic distance between poet and his created persona," in Late Medieval Prison Writing and the Politics of Autobiography (Oxford: Clarendon Press, 2004), p. 106. Anne E. B. Coldiron, more generally, notes Charles's refusal to offer explicit comment on his poetry's social context or purpose, in Canon, Period, and the Poetry of Charles of Orleans (Ann Arbor: University of Michigan Press, 1999), p. 24.

46. Geoffrey Chaucer, Troilus and Criseyde, ed. Barry Windeatt (London: Longman, 1984), IV:288-308; 323-329. For a discussion of the ransom trope in Troilus, see my "The Value of 'Eschaunge': Ransom and Substitution in Troilus and Criseyde," ELH 69 (2002), pp. 335-58.

47. One notable exception is Seth Lerer, who denies that the Devonshire's medieval quotations are mere "slack ventriloquism." He does not, however, consider this borrowing as a comment on imprisonment in particular, but rather as part of a more general commentary "on the imprisonments of love, on the enchainments of desire, and the social consequences of illicit longing" in court life (pp. 125-26).

48. See E. Seaton, "The Devonshire MS and its Medieval Fragments," Review of English Studies, n.s. 7 (1956); R. C. Harrier, "A Printed Source for the Devonshire Manuscript, Review of English Studies, n.s. 11 (1960); and Harrier, The Canon of Sir Thomas Wyatt's Poetry, pp. 25-26. For a more general account of Chaucer's early Tudor reception, see John Watkins, “'Wrastling for this world': Wyatt and the Tudor Canonization of Chaucer," in Refiguring Chaucer in the Renaissance, ed. Theresa M. Krier (Gainesville: University of Florida Press, 1998), pp. 21-39. 
49. Poem 43, "Womans herte vnto no creweltye" comes from The Letter of Cupid (CCCLXXIII in Thynne). Poem 45, "Yff all the erthe were parchment scribable," is adapted from the Remedy of Love (CCCLXVII in Thynne); Poem 46, "O marble herte and yet more harde pardie," is taken from a stanza in the voice of "LAmant" in La Belle Dame sans Mercy (CCXCI in Thynne).

50. Lerer, p. 153.

51. James Simpson, Reform and Cultural Revolution (Oxford: Oxford University Press, 2002), p. 154. 
